\title{
WORK OF THE ARCHÆOLOGICAL SURVEY OF INDIA*
}

\begin{abstract}
CIR LEONARD WOOLLEY'S report on the $D$ archæological survey of India is a compre. hensive document covering in some detail the large number of problems which presented themselves to its author during his three months' stay' in the country, and is characterized by $\Omega$ frankness of statement and freedom of criticism unusual in an official publication. It is, however, clear that with issues vital for the future of archæological studies and of interest not to India alone but also to the whole body of scholarship concerned with the scientific investigation of past civilizations, the situation necessitated plain speaking. As Sir Leonard points out, moneys from a reduced allocation from public funds were being wasted by misdirection, evidence was being destroyed through ignorance, incompetence or lack of training, and at the same time not only was no attempt being made to remedy lack of knowledge of India's cultural history or fill in the gaps in the archixological record, but also the very existence of these defects was barely realized.
\end{abstract}

The original terms of reference upon which Sir Leonard was invited to report by tho India Office in Warch 1938 covered the most promising sites or areas for excavation; the best methods for the speedy and fruitful development of exploration activities in general, regard being had not only to Government but also to non-official agencies, such as universities, learned societies, etc. ; the best method of training or selecting officers for exploration work; and finally, any general points bearing on the field of exploration and excavation not covered in the preceding.

This formulation of the problem of archeological exploration in India obviously leaves something to bo desired; and Sir Leonard was unlikely to overlook its defects as the charter of any commission he could undertake. He had in mind, of course, the report of the Museums Association on the museums of India. Ho pointed out to the India Office that matters coming under the head of "general points" might well bo of crucial importance, such as the character of the museums available for the custody of antiquities, finance, the capacities of the staff, and the like. Ho was assured that tho more complete the report, the more it would be welcomed.

Sir Leonard began his study of the situation with somo linowledgo of the conditions which placed difficulties in the way of "fruitful development of exploration activities". On further examination, however, ho found that his impression, gathered from the printed reports, that the unfavourable comparison of the work of the Department with that prior to the departure of Sir Joln Marshall in 1931 was due to financial stringency was entirely erroneous. After his inspection, he was forced to the conclusion "that the lack of money is not the principal reason for the setback in the progress of archæology in India - . an increase in the grant unaccompanied by other changes would actually do more harm than good, for the truth is tho Department is altogether

* A Report on the Work of the Archxological Survey of India. 3y Sir Lconard Woolley. Pp. II +47. (Simla: Department of Eduention, Health and Lands, n.d.) lacking in men trained for the work they have to do. Everywhere plenty of enthusiasm, intelligence and learning were encountered; but experience and train. ing were lacking and for this the members of the staff were not to blame."

In regard to tho staff, it is further pointed out that owing to the lack of differentiation and special. ization, each member is expected to bo a superman : ho is expected to be proficient in the work of conservation and excavation, may at any time be put in charge of a museum, and is in addition saddled with a mass of clerical work for which he has no special qualifications. Not. only is differentiation in function essential, but also the training and tuition required cannot be obtained within the department as at present constituted. For this and other reacons Sir Leonard recommends the appointment of a temporary adviser on archreology, who could deal with all the points at issue.

Sir Leonard then proceeds to expand this general criticism and to put forward his recommendations in several chapters of his report, each dealing with some specific aspect of the situation-sites for excavations, excavation by non-Government bodies, the selection and training of officers, the tork of an archrological department, excavation museums, general, and finance and personnel.

Apart from criticism of the work of the Depart. ment, the brief survey here given of the present state of archæological knowledge of India's past is illum. inating. By 1931 the work at Taxila on the Bhir mound had thrown a little light on the fow centuries preceding the Christian era, and Sirkap had done much for the Scytho-Parthian period. The religious monuments of the Buddhist age between the second and fifth centuries A.D. had been well oxemplified in tho north-west, and stray monuments of the Mauryan and Gupta period had been brought to light. MIohenjo-daro and Harappa had illustrated richly one phase of a culture about which no one could agree whether it was or was not Indian; and between it and Asoka, the next of which anything at all was known, there was a gap of two thousand years of blank ignorance. Of the cultural history of India not even tho skeleton existed, and even for those periods which may be called historical the sequence of cultural history was quite unknown. From coins and scattered inscriptions there had been constructed a regnal sequence to serve as a framework of history, but that was all, and in any excavation it was impossible, unless coins or dated inscriptions were forthcoming, to fit to that framerrork such discoveries as might be made.

As further evidence of the littlo prospect of advance. ment of knowledge, reference is made to the absence of the surest basis for the establishment of a chrono. logical scheme of cultural history-tho study of pottery. Except for the pottery of the Indus culture, no information is available, and a pottery typo cannot be dated within $\&$ thousand years. In South India the position is even worse. Of the tro, or possibly three, phases of 'prehistoric' culture, not even the sequence or time relation has been ascertained, and 
if the positive date of objects of clay, iron and bronze be demanded, the answer must allow of a margin of error of anything up to threo thousand years. Of the minor arts of the historic period nothing is known at all; between 'prehistoric' and historic thero is no correlation, and so far as cultural history is concerned, 'prehistory' may be said to continue to the sixteenth century A.D.

After such a scathing indictment of wasted oppor. tunity, almost any recommendation would probably bo acceptable; but Sir Leonard, while indicating where and on what considerations operations in the field might be extended, wisely counsels that in present conditions increased expenditure on excava. tion would bo harmful rather than a benefit, until the work of the Department has been placed on a sound basis.

Except in so far as they are directed to ensure the increase of archrological knowledge in accordance with scientific method, Sir Leonard Woolley's recommendations in detail are tho concern of the administrative authorities of the Government of India, rather than of interest to archaologists at large. In view of Sir Leonard's long experience and his wide and profound knowledge of the problems of archa. logical exploration, it may bo accopted that his recommendations are such as to secure that the archæological staff shall bo fully efficient to carry on excavations on sites chosen for their anticipated possibilities of advancing knowledge, in co-operation with a museum service also working to that end, the service being equipped and organized in such a manner as to afford facilities for the training of future officers ; while the curtailment of unnecessary and wasteful activities, especially in misdirected conservation, will avoid excessive increase in the Department's budget. One recommendation to which heartfelt welcome will bo given outside India is that for the appointment of two specially qualified officers to deal with the earlier prehistoric period, namely, the stone ages.

Of wider general interest are the sections of the report which deal with excavation by bodies other than the Survey and by organizations from outside. Müch disappointment has been expressed in ono quarter and another that enlargement of the provisions of the Antiquities Law has failed to attract nonofficial excavation. Sir Leonard rightly points out. that the responsibility is to be laid on a law which, liberal as it is in form, allows no prescriptive right. to the excavator of a share in the finds, but leaves this open as a matter of interpretation. This and other matters, including training in excavation for officials by reservation of the right of the Department to attach one of its officers to an expedition's personnel, are covered by amendments to tho law here suggested. Provision for early publication is also mado ; while tho importanco of early publication in accessible and suitable form at a reasonable price by the Survey itsolf is strongly urged.

\section{THE INFORMATIVE CONTENT OF EDUCATION}

\begin{abstract}
$\mathrm{T}$ HE second report of the Committee of the British Association appointed to consider the gaps in the content of education to which MIr. H. G. Wells directed attention in his presidential address to Section I (Education) at Nottingham was presented at the Lundee meeting. The first report revealed $a$ general agreement that Mr. Wells's suggestions were too wide in scope and too advanced for the capacity of the pupils concerned. There were, however, differences of opinion, and the present report shows in answer to inquiries by the committee the results attained by school-teachers in the studies commended by Mr. Wells. He, of course, when addressing tho Association, used grown-up language suitable for his audience but not for children of the age of 7-11 years. It is clear now that much of the information he wished to see taught can be learnt and might be acquired with advantage by young children.

The results here noted and tabulated by school. teachers are very promising, in view of the small portion of time available for such teaching, and it is really important. We are not getting at present anything like the return we are entitled to expect from the vast sums spent yearly on education, and this criticism applies particularly to science and such allied subjects as geography, which reaches out on one side to history and on the other to scientific research. Though experts may differ as to the way in which geography should be taught, every one will agree that small children should learn to understand and use maps, so that they can find their own way about with confidence and help others, when questioned, by intelligent replies.
\end{abstract}

Nature study, so far, has had but poor results, though a host of useful books are available. One thing is evident : young children must, whenover it is possible, have the actual objects used before them. The plot of ground designed by one school for study is an excellent idea. Here "the course is recreative rather than formal, but at the same time special studies are made whero accuracy is insisted on". The comment shows the survival of tho view that education must be carefully dissociated from amusement. Biology for tho young is not easy, and is perhaps best. taken in connexion with personal hygiene. Many friends of education have long been convinced that too much is attempted in the curriculum of to-day. Thus the "Civics Course" of one school reminds us that in Russia this subject with a pronounced tinge of 'red' was forced on schoolmasters, who repudiated it and went back to teaching on the old lines. Here at least, in Mr. WVells's requirements, we are concerned with practical knowledge promoting good health and the pleasure and utility of good observation for all children. The juvenile standard of intelligence in this way in children in Great Britain is not equal to that shown by foreign children. Knowledge of other lands and ways of life is rightly emphasized. The sort of patriotism which declares that your own country is the only one which is right is out of date.

The juvenile sections of freo libraries should be a great help and more useful, as implying effort, than B.B.C. talks. In general, the schemes of work printed are excellent, but a pertinent question asked is : How can the teacher find time or opportunity to keep up with all this, especially when he is confronted with the very wide method of stimulus known as 